\title{
The Impact of Austerity in the Framework of Corporate Rescue and the Rights of Workers in the EU: A Road to Recovery?
}

Dr Jennifer L. L. Gant

Lecturer/Senior Lecturer in Law

Centre for Businesses and Insolvency Law

Nottingham Law School

Nottingham Trent University

50 Shakespeare Street

Nottingham NG1 4FQ

United Kingdom

Email : Jennifer.Gant@ntu.ac.uk

Phone : +447787377158

\section{Dr Alexandra Kastrinou}

Lecturer/Senior Lecturer in Law

Centre for Businesses and Insolvency Law

Nottingham Law School

Nottingham Trent University

50 Shakespeare Street

Nottingham NG1 4FQ

United Kingdom 


\begin{abstract}
The financial crisis and the sovereign debt crisis have been attributed to a number of causes. Whether these are economic, social, cultural, or legal, they are all by and large also political. The aim of this article is not to delve into the myriad of heated political arguments that continue to dominate the scene, but to assess the impact of the financial crisis on the employment protection rights and the corporate rescue regimes in Greece, Portugal, France, and the United Kingdom. In light of the crisis, the rights of the workforce have been severely compromised to afford financially troubled companies a greater opportunity to recover. In order to minimise the catastrophic impact of financial turmoil on their economy and society, all four jurisdictions introduced reforms to their labour codes and corporate rescue mechanisms, often in the name of austerity.

This article will offer a snap shot of the changes, their effects, and an assessment whether or not the reforms of pre-insolvency regimes have operated as an effective embankment for the protection of social and economic welfare. The purpose of this piece is to shed a light on the changes that have occurred that have affected employment rights in the domestic legal systems of individual member states, as influenced to some extent by the EU in its expectations of improvements to increase labour market flexibility, and whether corporate rescue mechanisms in individual member states are able to provide some counter balance to the erosion of employment rights generally.
\end{abstract}




\title{
The Impact of Austerity in the Framework of Corporate Rescue and the Rights of Workers in the EU: A Road to Recovery? ${ }^{1}$
}

\author{
By: Dr Jennifer L. L. Gant ${ }^{2}$ and Dr Alexandra Kastrinou ${ }^{3}$
}

\section{Introduction}

The financial crisis and the sovereign debt crisis that followed it have been attributed to a number of causes. Whether these are economic, social, cultural, or legal, they are all by and large also political. The aim of this article is not to delve into the myriad of heated political arguments that continue to dominate the scene, but to assess the impact of the financial crisis on the employment protection rights in Greece, Portugal, France, and the United Kingdom and to examine its impact on their corporate rescue regimes with a view to understanding what the legislative and social changes may mean for the future of these individual nations, their people and businesses, and perhaps for the EU and Eurozone as a whole. In light of the crisis, the rights of the workforce have been severely compromised to afford financially troubled companies a greater opportunity to recover. In order to minimise the catastrophic impact of financial turmoil on their economy and society, all four jurisdictions introduced reforms to their labour codes and corporate rescue mechanisms, often in the name of austerity.

This article will only offer a snap shot of the important changes that have occurred, the effects as understood at the current level of research, and an assessment whether or not the reforms of pre-insolvency regimes in particular have operated as an effective embankment for the protection of social and economic welfare, the former of these having already been significantly reduced throughout the EU. It is not intended that this piece be viewed as an indictment on the EU approach to matters of sovereign debt, which member states then had to manage from their own legal and economic perspectives. Rather, it is intended to shed a light on the changes that have occurred that have affected employment rights in the domestic legal systems of individual member states, as influenced to some extent by the EU in its expectations of improvements to increase labour market flexibility, and whether corporate rescue mechanisms in individual member states are able to provide some counter balance to the erosion of employment rights generally.

\section{The Financial Crisis, Sovereign Debt, and the Euro Plight}

The EU has changed significantly since the beginning of the financial crisis of 2007. Where there was once an unbridled emphasis on the protection and creation of workers' rights in many nations, these were tempered by pressing financial issues of rampant sovereign debt. Not every European country experienced the financial crisis or suffered from it in the same way. This is due in part to the position in their economic cycles, the effects of membership of the Eurozone, and the spending habits of their governments and consumers.

The issues separating the southern and northern European countries in the effects of the financial crisis can be traced in part back to the creation of the European Monetary Union. The decision to enter into a common currency, while in principle strictly financial, had huge political and social implications as it provided an unprecedented connection between the

\footnotetext{
${ }^{1}$ A presentation of the content of this article was made at the INSOL Europe Academics Forum in Istanbul, Turkey on 8-9 October 2014.

${ }^{2}$ Lecturer/Senior Lecturer in Law, Nottingham Law School, Nottingham Trent University.

${ }^{3}$ Lecturer/Senior lecturer in Law, Nottingham Law School, Nottingham Trent University.
} 
destinies of European nations who had relinquished one of the most fundamental functions of sovereignty: the control of their own currency and monetary policy. ${ }^{4}$ While the launching of the Euro was met with hope that it would create a wave of competitive, reforms across Europe, not every country succeeded in implementing long-lasting reforms that would help them to cope better with the discipline of living within a single currency. ${ }^{5}$ Peripheral countries, of which Greece and Portugal are two, made strenuous efforts to qualify for the Euro by reducing public spending and holding down wages and other costs, but in some countries these provisions were relaxed once they were admitted to the monetary union. ${ }^{6}$ In addition, the single currency also equalised the competition between exporting countries as depreciation could no longer be used as a means to lower costs. As such, those countries who had to raise their costs to meet a standard rate of currency effectively lost a portion of their market share within the EU, leading to trade deficits and contributing in part to the sovereign debt crisis. ${ }^{7}$ The single monetary policy therefore created tensions between countries positioned along different phases of their economic cycles, which in times of crisis, led to an asymmetric effect as countries could no longer undertake the devaluation of their currency in order to bolster their economies. ${ }^{8}$

Due to being a part of the Euro, Greece and Portugal could not address their mounting problems by devaluing their currency. They were also unable to address their fiscal problems through inflation given the European Central Bank's aversion to it. ${ }^{9}$ With no recourse to devaluation or inflation, the Euro became a straightjacket for those member states struggling with sovereign debt. To avoid sovereign default and financial collapse, Greece and later Portugal needed financial assistance. ${ }^{10}$ Greece and Portugal agreed to a Memoranda of Understanding $^{11}$ in exchange for bail out money conditional upon certain changes to economic policy based on expected targets that would be periodically reviewed. The targets listed included fiscal policy objectives of reducing the government deficit accompanied by a number of recommendations on how to do so; financial sector regulation and supervision; fiscal-structure measures; labour market and education; housing market; and other framework conditions including improving the functioning of the judicial system. ${ }^{12}$ In order to meet the targets set out in the MoU, Greece and Portugal adopted austerity measures to decrease the costs within their economies by cutting employment and wages and by introducing structural policies aimed to increase wage and price flexibility. These measures aimed to deregulate the labour market to increase competition, embarking on an internal devaluation to meet the objectives in the MoU as construed by the "troika" of the International Monetary Fund, the EU and the European Central Bank. The domestic policy approaches adopted in response to the MoU worsened liquidity problems, causing markets to further doubt the potential for the countries to repay their loans, thus asking for higher interest rates to mitigate investment risk, which in turn worsened their fiscal position. ${ }^{13}$ The bailout itself was not only an attempt to help the ailing Southern European countries, although its effects on the people of Greece and

\footnotetext{
${ }^{4}$ Franco Pavoncello, "One for All, All for One: The Euro in Crisis” (2011) May/June World Affairs 59-70, 62.

5 James A Caporaso and Min-Hyung Kim, "The Maastricht Treaty at Twenty: A Greco-European Tragedy?" (2012) 34(7) J Europ Integration 769,778 .

6 "The European Central Bank: Ten Years on, Beware the Porcine Plot" (2008) June 5 $5^{\text {th }}$ The Economist http://www.economist.com/node/11496844 Accessed 14 August 2014.

${ }^{7}$ Costis Hadjmichalis, "Uneven Geographical Development and Socio Spatial Justice and Solidarity: European Regions after the 2009 Financial Crisis" (2011) 18 European Urban and Regional Studies 254, 259-264.

${ }^{8}$ Pavoncello (n4) 62.

${ }^{9}$ Klaus Armingeou and Lucio Baccaro, "Political Economy of the Sovereign Debt Crisis: the Limits of Internal Devaluation" (2012) 41(3)

ILJ 254, 255-256 \& 263-265.

${ }^{10}$ Pavoncello (n4) 59-65.

${ }^{11}$ Hereafter referred to as an "MoU".

12 Portugal Memorandum of Understanding on Specific Economic Policy Conditionality (17 May 2011) available from http://ec.europa.eu/economy_finance/eu_borrower/mou/2011-05-18-mou-portugal_en.pdf first accessed 26 February 2017.

${ }^{13}$ Armingeou and Baccaro (n9) 255-256 \& 263-265.
} 
Portugal serve to contradict this proposition, but also to keep them from defaulting on their sovereign debt obligations, which would cause severe damage to the European banks. Thus the bail-outs were also in the self-interest of the rescuers and the EU economy overall. ${ }^{14}$

The EU entered into a number of new pacts and treaties, both within the Eurozone and internationally, to combat and prevent further economic destabilisation. Among its policies for dealing with the crisis was the flexibilisation of the labour market by encouraging member states to adjust labour market rigidities and contain pension expenditure. These policies have generally affected only the Eurozone countries; thus the UK has largely been left to manage its labour system as it sees fit. This did not stop the UK from taking up the deregulation baton, however, as a number of changes have been made that undermine employment protection. The implementation of the Euro Plus Pact, which was thrust in an "indelicate manner" on the other heads of government in the European Council by France and Germany, aimed to foster competitiveness and employment, contribute to the sustainability of public finances, and reinforce financial stability. While these non-binding instruments lack legal force, the response of the EU to the crisis presented a pernicious threat to workers due to deregulation of employment rights at national levels, prompting the risk of an EU driven "race-to-the-bottom", an element that has previously been the focus of prevention in EU social policy. ${ }^{15}$ Thus instead of the EU as an instrument of protection for vulnerable employees, it has since 2007 consistently undermined the level of protections it once supported. In order to meet the targets of the MoU and repay the bail out money, both Greece and Portugal significantly cut pay and jobs in the public sector, curtailed pensions, and restricted pension rights. Retirement age was increased, a threshold for pensions was introduced, and pensioners lost a considerable part of their pensions due to the abolition of the Christmas, Easter, and summer bonuses. Portugal went a step further and applied a special levy on self-employed people, having the same effect to those changes made for employees. Welfare benefits became less generous and more conditional with less protection for the unemployed along with cuts in social and public works budgets. ${ }^{16}$ Changes to Portuguese law came to resemble the lower level of protection and workers' rights that exists in the UK. ${ }^{17}$

\section{The Impact of the Financial Crisis on Workers' Rights}

Not every jurisdiction has reduced workers' rights to the same degree; however, every country has taken some steps within their labour and employment law systems with a view to improving their economic position. Fundamental changes to working time and atypical employment (albeit often temporary) were made throughout the EU as a response to the economic crisis. Changes to redundancy rules, industrial relations structures and processes also occurred, affecting the social dialogue, often by engaging in measures to decentralise collective bargaining, which have tended toward permanence. Regardless of whether such changes were permanent, they had the effect of undermining the protective role of labour and employment law, placing workers in a more precarious position than they would have

\footnotetext{
${ }^{14}$ Barry Eichengreen, “The Euro’s Never-Ending Crisis” (2011) March Current History 91.

${ }^{15}$ Catherine Barnard, "The Financial Crisis and the Euro Plus Pact: A Labour Lawyer's Perspective" (2012) 41(1) ILJ 98, 99, 104-105.

${ }^{16}$ Sotirios Zartaloudis, "The Financial Crisis has Badly Damaged the Greek and Portuguese Welfare States" The London School of Economics and Political Science: European Politics and Policy Blog (2014) available from http://blogs.lse.ac.uk/europpblog/2014/09/23/thefinancial-crisis-has-badly-damaged-the-greek-and-portuguese-welfare-states/ first accessed 29 September 2014.

${ }^{17}$ For a description of the EU response to the crisis, see "Economic Crisis in Europe: Causes, Consequences and Responses" (2009) 7 European Economy - Economic and Financial Affairs; Barnard (n15); Maurizio Ferrera, "Social Europe and its Components in the Midst of the Crisis: A Conclusion" (2014) 37(4) W Eur Pol 825.
} 
enjoyed prior to the financial and sovereign debt crisis. ${ }^{18}$ In addition, pensions were significantly affected by the crisis throughout the EU member states. Each jurisdiction under examination amended its labour code in order to simplify hiring and dismissal rules. ${ }^{19}$

Greece

Greece took steps in line with the protective function of labour law during the initial stages of the crisis; however, its perspective changed completely in response to the need to meet the targets set by the MoU. ${ }^{20}$ The financial crisis revealed endemic weaknesses in the Greek welfare system and employment regime, in part due to the dualist labour market comprised of an official public pool that makes its contributions and is protected by the employment laws in place, and a shadow labour market that is subject to the precariousness of the poor economic climate and is not generally entitled to the same level of social protection. Much of Greek public infrastructure has been developed through the use of structural loans, which increased sovereign debt while encouraging household consumption. Thus when Greece had to resort to the troika for rescue, the austerity measures imposed as a result of the MoU targets had a severe impact on its welfare system. ${ }^{21}$ The overall goals of the MoU were to eliminate fiscal imbalances by achieving fiscal surpluses; to improve competitiveness; and to improve liquidity for Greece until its return to the financial markets. ${ }^{22}$ In order to do this, among other changes, wages would need to be lowered. ${ }^{23}$

When the austerity measures were implemented by the Greek government, there was a rapid reduction of salaries in the public sector, which were transmitted quickly to the private sector, reducing the purchasing power of the Greek people. This in turn created a deep and persistent recession, leading to a steep rise in unemployment. Greece also had to focus on reducing its debt burden, which diverted public expenditure from social benefits, health, education, and welfare provisions. Unemployment continued to rise, and peaked at $27.9 \%$ in July 2013, but remains the highest in the EU at $23 \%$ as of February $2017 .{ }^{24}$ The level and depth of poverty and personal despair intensified, not the least due to the fact that the unemployment fund is based exclusively on contributions, which those who had previously worked in the shadow economy or as undeclared workers will have not contributed to. Thus the social protection available is wholly inadequate to the nature of the Greek labour market. ${ }^{25}$

The structural reforms to labour law were undertaken based on the premise that labour market regulation constituted a significant barrier to growth. Prior to the crisis, there had been significant resistance to any flexibilisation of the labour market through the implementation of laissez faire policies on collective bargaining. By the time of the crisis, Greece had some of the strictest employment protection legislation in the EU. ${ }^{26}$ In counterpoint to Greece's

\footnotetext{
${ }^{18}$ Stefan Clauwaert and Isabelle Schomann, “The Crisis and National Labour Law Reforms" (2012) Working Paper 2012.04 European Trade Union Institute 8.

${ }^{19}$ Andre Pestana Nascimento, "Relaciones Laborales y Regulacion de los sistemas de Prevision Social: A Reforma Laboral em Portugal" (2012) Actualidad Jurídica Uría Menéndez, Especial reformas estructurales, 47 available from http://www.uria.com/documentos/publicaciones/3603/documento/a5.pdf?id=4410 first accessed 15 August $2014,50$.

${ }^{20}$ Prof Costas Papadimitriou, "The Greek Labour Law Face to the Crisis: A Dangerous Passage Towards a New Juridical Nature" (2013) European Labour Law Network - Working Paper Series, ELLN Working Paper 3/2013 4.

${ }^{21}$ Constantine Dimoulas, "Exploring the Impact of Employment Policy Measures in the Context of Crisis: The Case of Greece" (2014) 67(2) Int'1 Soc Sec Rev 49, 49-55.

${ }^{22}$ Sotirios Zartaloudis, "The Impact of the Fiscal Crisis on Greek and Portuguese Welfare States: Retrenchment before the Catch-up?" (2014) 48(4) Social Policy and Administration 430-449, 438.

${ }^{23}$ Papadimitriou (n20).

${ }^{24}$ Data from Eurostat, available from

https://www.google.co.uk/publicdata/explore?ds=z8o7pt6rd5uqa6_\&met_y=unemployment_rate\&idim=country:el:es:it\&hl=en\&dl=en first accessed 26 February 2017.

${ }^{25}$ Dimoulas (n21) 49-55.

${ }^{26}$ Aristea Koukiadaki and Lefteris Krestos, "Opening Pandora's Box: The Sovereign Debt Crisis and Labour Market Regulation in Greece" (2012) 41(3) ILJ 276, 278-280.
} 
previously extremely employee friendly policies, the austerity policies applied in response to MoU targets were among the most severe fiscal austerity packages in Europe since the end of the Second World War. ${ }^{27}$ Employment remains highly fragile in those economies such as Greece that have been subject to austerity measures and where business restructuring and its effect on job security is an ongoing reality. ${ }^{28}$

\section{i. Wages}

In Greece, the minimum wage decreased by approximately $22 \%$ for adults and $32 \%$ for youths under $25 .{ }^{29}$ Public sector employees suffered a flat reduction in monthly salary as well as in holiday and annual leave premiums. Pay was also frozen and incapable of being affected by collective bargaining. Pay overall decreased by an average of 50\% since the beginning of the sovereign debt crisis. This is due in part to the decrease in overtime pay, rendering the labour force less expensive and more flexible. ${ }^{30}$

Wages were also affected by the introduction of partial unemployment as a measure that permits a company to alternatively employ employees for a number of days less than originally planned in their employment contract, along with the commensurate reduction in pay. ${ }^{31}$

\section{ii. Atypical Contracts}

Greece changed its rules on fixed term contracts, increasing the maximum term from two to three years. ${ }^{32}$ There was also an increased utilisation of rotational work and fixed term contracts in order to increase flexibility. ${ }^{33}$ That said, Greece also introduced a new scheme for the protection of employees on reduced working hours in medium sized companies. ${ }^{34}$

Greece also introduced new types of employment contracts that effectively reduced the protection that normal employment would provide. For example, a "youth contract" has been introduced through which young workers are hired on wages $20 \%$ less than the previous rate for first job, with a two-year trial period, no social contributions from employers, and no entitlement to unemployment benefits at the end of the contract. ${ }^{35}$

\section{iii. Hiring and firing}

One of its most serious austerity measures related to the reduction of the costs of hiring and firing employees. ${ }^{36}$ Greek law did not require the employer to justify the dismissal of an employee as a potentially fair reason, an aspect of its labour code that was in place prior to the crisis. Despite this fact, Greek severance packages were so generous that its labour system was still considered highly inflexible due to the costs of dismissal. Following the crisis, notification periods were significantly reduced, thereby reducing the potential for severance

\footnotetext{
${ }^{27}$ Hadjmichalis (n7).

${ }^{28}$ Angelika Muller, "Employment Protection Legislation Tested by the Economic Crisis: A Global Review of the Regulation of Collective Dismissals for Economic Reasons" (2011) International Labour Office, Dialogue in Brief No. 3.

${ }^{29}$ Dimoulas (n21) 54.

${ }^{30}$ Papadimitriou (n20) $9 \& 12$

${ }^{31}$ Ibid 9.

${ }^{32}$ Clauwaert and Schomann (n18) 11.

${ }^{33}$ Dimoulas (n21) 54.

${ }^{34}$ Daniel Clegg, "Labour Market Policy in the Crisis: the UK in Comparative Perspective" (2010) 18(1) The Policy Press 5, 11.

${ }^{35}$ Clauwaert and Schomann (n18) 11.

${ }^{36}$ Dimoulas (n21) 56.
} 
compensation, with a concomitant reduction in the cost of dismissal. ${ }^{37}$ While justified in the name of competitiveness, these changes promoted the adoption of a short term solution for reducing costs via dismissals, rather than pursuing longer term strategies, further undermining employment security. ${ }^{38}$

\section{iv. Redundancy}

The law of 2010 raised the collective dismissals from four to six employees dismissed in enterprises with more than 20 employees and from two to five percent of employees in enterprises employing more than 150 people. ${ }^{39}$ It should be noted that this was still far more protective than the Collective Redundancies Directive, ${ }^{40}$ which stipulates 10 as the minimum employees in a company of more than 20 workers and ten percent in establishments employing at least 100 employees. Thus despite the changes applied to its collective redundancy regime, Greece remains highly protective in those circumstances relative to other EU member states. Redundancy compensation has also been reduced by $50 \%{ }^{41}$

\section{v. Collective Bargaining}

The fundamental nature of Greek collective bargaining changed in the wake of the crisis as aspects that had formed part of the fundamental industrial character have been wholly displaced, specifically in terms of the hierarchy of collective agreements, the reduction in potency of branch level collective agreements, the reduction in the extension period of agreements following their expiry, and the abandonment of mandatory arbitration in the settlement of disputes. ${ }^{42}$ Representation criteria of social partners was reviewed and trade union prerogatives were extended to other bodies of worker representation. ${ }^{43}$ Greece also placed legal restrictions on the role of collective bargaining through the prohibition of wage increases until the unemployment rate reduced below 10\%, a target that seems out of reach given the current unemployment rate noted above. ${ }^{44}$ In light of the troika review of the progress of implementing reforms in the labour laws of Greece, collective bargaining became the topic of ongoing discussions on the possibility of unilaterally limiting the employee right to strike.

\section{vi. Access to Social Welfare}

Greece tightened restrictions on the access to social benefits as well as reducing the duration and level of payments as a part of their austerity measures. ${ }^{45}$ Further, the "workfare" employment measure expanded the use of fixed-term, quasi-employment in the community and public services, providing a minimum fixed income but few employment rights. Under the workfare rules, unemployed youth, long term unemployed, and the working poor with low annual incomes are granted five months of employment benefit in exchange for working six hours per day in community services. These workers replaced the need to hire within the

\footnotetext{
${ }^{37}$ Papadimitriou (n20) 9.

${ }^{38}$ Koukiadaki and Krestos (n26) 286-287.

${ }^{39}$ Muller (n28) 4; Dimoulas (n21) 54; and Koukiadaki and Krestos (n26) 287.

${ }^{40}$ Directive 98/59/CE of 1998 on the approximation of the laws of the Member States relating to collective redundancies, OJ L 225/16.

${ }^{41}$ Dimoulas (n21) 54.

${ }^{42}$ Papadimitriou (n20) 16-17.

${ }^{43}$ Clauwaert and Schomann (n18) 10 and 14.

${ }^{44}$ Dimoulas (n21) 54.

${ }^{45}$ Ibid 56.
} 
public service, which had been frozen in response to the MoU. ${ }^{46}$ However, Greece introduced subsidies for employers who recruit an unemployed worker. ${ }^{47}$

\section{Portugal}

Upon joining the European Union, Portugal was entitled to a large amount of structural funds with the aim of building up its infrastructure. Since 1986, the Portuguese economy has been dependent on funds coming from the EU as a strategic means to invest and as a way of attracting more foreign direct investment. The economy was thereby quite vulnerable to the withdrawal of such investment. ${ }^{48}$ A commonly held view was that Portugal's sovereign debt crisis was directly related to its entering the framework of the Euro without having the economic fundamentals in place to survive the rigours of a single currency. Even before joining the Euro, while making efforts to qualify for membership by running a tight monetary policy to contain inflation and interest rates, there was a noticeable slowing of economic growth, particularly at the turn of the millennium. ${ }^{49}$ As early as 2005 , austerity measures had already been enacted to combat an impending financial crisis that had been brewing since joining the Euro in $2001 .^{50}$

What is particular to the Portuguese economy that is not common among its other peripheral colleagues is that its constitutional and legal order significantly empowers the more organised segments of the workforce. Prior to its bail-out, Portugal had the most rigid employment protection laws in the Eurozone. ${ }^{51}$ Among developed nations it ranked last in terms of labour freedom ${ }^{52}$ and it has been asserted that such rigidity has impaired firm performance. ${ }^{53}$ While joining the Euro did have the effect of impairing Portugal's ability to provide cheap products to the European market due to the levelling effect of the common currency, its highly rigid and protective labour system was also at the root of Portugal's competitiveness problem, but this was also an inherently political issue. ${ }^{54}$ The Portuguese government negotiated with its social partners a new labour code that aimed to make the labour market more flexible. Despite the rigidity and superior power of Portugal's social partners, these far reaching changes were supported by the main employers' organisations, the second largest trade union confederation, and the socialist-social democratic General Union of Workers. Though vehemently opposed by the largest union, the Communist General Confederation of Portuguese Workers, the reforms were passed in November 2008. ${ }^{55}$

In 2010, additional emergency austerity measures were introduced as a result of continued market pressure and successive downgrading by major credit rating agencies. In March 2011, in order to avoid a failure requiring the resort to external rescuers, further additional measures were introduced that would have made cuts to welfare and health, as well as freezing pensions, but this was not approved by parliament. Thus Portugal also resorted to the troika

\footnotetext{
${ }^{46}$ Ibid 59.

${ }^{47}$ Clegg (n34) 9.

48 Jose M Magone, "Portugal is not Greece: Policy Responses to the Sovereign Debt Crisis and the Consequences for the Portuguese Political Economy" (2014) 15(3) Perspectives on European Politics and Society 346, 348.

${ }^{49}$ George Bragues, "Portugal's Plight: The Role of Social Democracy" (2012) 16(3) The Independent Review 325,326 \& 337.

${ }^{50}$ Zartaloudis (n22) 437-443.

${ }^{51}$ Bragues (n49) 338-339.

52 Jorge A Vasconcellos, Portuguese Institute for Economic Freedom available at http://institutoliberdadeeconomica.blogspot.co.uk/ accessed 24 September 2014.

53 Pedro S Martins, "Dismissals for Cause: The Differences that just Eight Paragraphs Can Make" (2009) 27 Journal of Labour Economics 257.

${ }^{54}$ Bragues (n49) 339.

55 Jose M Magone, "Portugal” (2009) 48 Eur J Pol Res 1080, 1081.
} 
for assistance and agreed to its own MoU, implementing cuts in response to the targets set that went well beyond those suggested in the MoU itself. ${ }^{56}$

The labour market in Portugal shares some similarities to the Greek as it is also of a dual character. A large proportion of workers in large enterprises and the public sector enjoyed a high level of employment protection, while those in micro, small, and medium sized enterprises are less privileged as these companies often do not respect employment protection legislation and therefore demonstrate a high level of flexibility in hiring and firing. It is this latter labour sector that tends to be the hardest hit in times of crisis and explains the rapid rise in unemployment that occurred in similar fashion to Greece, despite the differences in the systems. ${ }^{57}$ The MoU suggested several areas in need of labour reform: reduction of long term unemployment and strengthening social protections; reform of the employment protection legislation in order to combat the segmentation of the labour market and to facilitate the movement of workers between professions, markets and sectors (flexibilisation of the labour market); improve flexibility of working time rules in order to fit the needs of peak business times and thus augment the competitiveness of Portuguese businesses; to connect the costs of labour with effective job creation; and to approve legislation that serves to improve the employability of youth and of other traditionally disadvantaged categories of workers. ${ }^{58} \mathrm{~A}$ new labour code entered into force on 1 August 2012 which attempted to integrate the changes required in the MoU, under a flurry of cries against the constitutionality of the reforms, which were summarily ignored by the government in power at the time. ${ }^{59}$

\section{i. Wages}

Pay freezes were introduced for public sector workers as were freezes on promotions. Salaries were cut by between 3.5 and $10 \%$ in 2010. Salary and holiday bonuses were also abolished. ${ }^{60}$ In addition and as a subset of a reduction in wages, the Portuguese MoU had a considerable influence on the reform of working time rules, widening overtime options significantly. Previously, employees were paid $50 \%$ of their hourly wage for the first hour of overtime, $75 \%$ for additional hours and $100 \%$ for work on holidays and Sundays. These rewards were reduced by half. ${ }^{61}$ In addition, the working week was increased from 35 to 40 hours for public sector workers and extended normal working hours for all employees by two hours per day in order to cut overtime costs. Four public holidays were also abolished. ${ }^{62}$

\section{ii. Atypical Contracts}

Portugal also rendered the rules on fixed term contracts more flexible by increasing the maximum length of a fixed term contract from 6 months to 3 years ${ }^{63}$ with the potential to renew twice not exceeding eighteen months in total before an indeterminate contractual term is applied. ${ }^{64}$ These changes in addition to the changes to dismissal rules generally saw a shift away from indeterminate contracts toward fixed term contracts due to the constitutionally

\footnotetext{
${ }^{56}$ Zartaloudis (n22) 437-443.

${ }^{57}$ Magone (n48) 349-350.

${ }^{58}$ Nascimento (n19) 48.

59 "Controversial New Labour Code Comes into Force" European Industrial Relations Observatory Online, available from http://www.eurofound.europa.eu/eiro/2012/05/articles/pt1205019i.htm accessed 26 September 2014.

${ }^{60}$ Zartaloudis (n22) 441

${ }^{61}$ Clauwaert and Schomann (n18) 8-9.

62 Zartaloudis (n22) 442.

${ }^{63}$ Clauwaert and Schomann (n18) 11.

${ }^{64}$ Nascimento (n19) 51.
} 
imposed difficulties of ending indeterminate term contracts, ${ }^{65}$ rendering job security far more precarious for many workers.

\section{iii. Hiring and Firing}

Prior to the reforms to the Portuguese labour code, the Portuguese constitution prohibited dismissals without a just cause or for political or ideological reasons. Essentially, it was impossible to dismiss an employee who had not behaved in an illicit or deviant manner having such gravity that it effectively destroyed the employment relationship. ${ }^{66}$ Following the introduction of the new labour code, there was an extension in the concepts of unsuitability and the extinction of worker positions in order to make individual dismissals easier. An employer can now establish non-discriminatory criteria for dismissals, drawing Portugal's redundancy rules in line with what currently exists in the UK. Employers are also no longer obliged to offer a transfer to another suitable position when dismissing an employee for either unsuitability or the extinction of his job. ${ }^{67}$

Portugal also reduced severance pay for workers from 30 days for every year of service with no maximum limit with a three-month minimum to 20 days per year of service with no minimum severance pay with a cap at 12 months' wages or 240 times the minimum wage. ${ }^{68}$ Further reforms were announced that brought the Portuguese severance packages into line with EU averages. Probationary periods for new employees were also raised from 3 to 6 months.

\section{iv. Redundancies}

Prior to reforms, the system governing collective redundancies in Portugal was rigid, requiring verification of the reasons for the dismissals, and strict formal procedures. ${ }^{69}$ More flexible redundancy legislation was introduced, affecting the costs of lay-offs and other measures to reduce the financial burden on undertakings themselves. Eligibility and qualification periods were amended, providing more scope for worker dismissal, and redundancy benefits were reduced. In addition, Portugal introduced an "employers' compensation fund" to finance redundancy benefits. ${ }^{70}$

\section{v. Collective Bargaining}

Portugal also underwent amendments to the procedures governing collective redundancies aimed at flexibilising existing legislation. ${ }^{71}$ It pushed for more firm level collective agreements and even individual agreements between employers and employees. ${ }^{72}$ There was a move toward making it possible for lower level bargaining to deviate unfavourably from higher level collective agreements or even statutory legislation. The representation criteria of social partners was reviewed and trade union prerogatives were extended to other bodies of worker representation. ${ }^{73}$ Portugal also made it impossible to bargain for conditions better than

\footnotetext{
${ }^{65}$ Ibid.

${ }^{66}$ Ibid 50

${ }^{67}$ (n59).

${ }^{68}$ Zartaloudis (n22) 442.

${ }^{69}$ Nascimento (n19) 50.

${ }^{70}$ Clauwaert and Schomann (n18) 12-13.

${ }^{71}$ Ibid.

${ }^{72}$ Zartaloudis (n22) 442.

${ }^{73}$ Clauwaert and Schomann (n18) 10 and 14.
} 
the new labour code put into place. ${ }^{74}$ The overall effect of these changes represents a move toward decentralisation of trade union operation and served to weaken trade union action and representation at all levels of bargaining. It also weakened the acquired social rights achieved by trade unions at national and local levels, lowered the standard of recognised rights, and affected fundamental employment conditions and social protections. ${ }^{75}$

\section{vi. Access to Social Welfare}

In Portugal, the maximum amount of unemployment insurance was reduced by a third (from three times to only twice the social support index), and the maximum length of time the benefit could be paid was reduced from 900 to 540 days. ${ }^{76}$ However, there was also an increase in the maximum duration of entitlement to non-contributory social benefit for unemployment scheme. ${ }^{77}$

\section{France}

The plight of Greece and Portugal are only slightly reflected in the effects that have been felt on the welfare states of the central European countries, such as France and Germany. Many states reformed in ways that reduce entitlements, protection, and the welfare of precarious or unemployed workers. Temporary working also became more common, which had wide ranging implications for worker equality due to lower employment security and earning power. However, while these issues became common throughout the Eurozone and the UK, France's protection for temporary workers remained the highest in Europe, despite an apparent need to deregulate temporary work in order to inject flexibility in the labour market and deal with high unemployment rates like the rest of the EU. ${ }^{78}$ Further, France introduced additional protections and assistance for their unemployed, including subsidised employment contracts and the extension to new groups of workers a Professional Transition Contract that provided intensive help with a job search over a twelve month period, during which a beneficiary was also entitled to higher benefit payments. ${ }^{79}$

While France did not sink to the same depths of financial despair as Greece and Portugal, it has nonetheless sunk into a case of collective pessimism since the economic crisis in 2008. The economic crisis caused a fundamental disillusionment with the neo-liberal economic model and in the benefits of globalisation for France, though this scepticism has been prevalent for decades in the French psyche. By many, the welfare state was no longer perceived as sufficiently protective and the EU has often been viewed as less than a force for positive change than a source of economic difficulties. Thus nationalism also rose along with unemployment rates, faltering economic growth, and rising popular discontent. ${ }^{80}$ While the highly regulated French economic model appeared to have been weathering the crisis better than the liberal English model, it was still nonetheless severely impacted by it. ${ }^{81}$

The French banking sector was also not as severely compromised by the financial crisis as were the systems of the UK and Germany. This has been in part attributed to the way in

\footnotetext{
${ }^{74}(\mathrm{n} 59)$.

${ }^{75}$ Clauwaert and Schomann (n18) 10 and 14.

${ }^{76}(\mathrm{n} 59)$.

${ }^{77}$ Clegg (n34) 12.

${ }^{78}$ Tim Vlandas, "The Politics of Temporary Work Deregulation in Europe: Solving the French Puzzle" (2013) 41 Pol \& Soc'y 425, 426-417.

${ }^{79}$ Clegg (n34) 9.

${ }^{80}$ Sarah Waters, "The 2008 Economic Crisis and the French Narrative of National Decline: Une Causalite Diabolique" (2013) 21(3) Modern and Contemporary France 335, $339 \& 350$

${ }^{81}$ Georges A Cavalier, "French Interventions in the Financial Crisis" (2010) 35(3) Brook J Int'l L 786, 787.
} 
which France internationalised its banking sector with what has been viewed as a more diverse approach, with a combination of retail investment as well as corporate lending and investment banking, the latter two of course being the cause of much of the banking turmoil that caused the crisis. Although French banks were still heavily engaged in market-based banking, they were far smaller investors in toxic assets and other high risk activities. ${ }^{82}$ While the financial crisis did not bring substantial changes to the French banking system, the Banking Relief Act was adopted in October 2008 with the purpose of creating two special purpose vehicles (a Refinancing Company and a Recapitalization Company) with the aim of establishing a State guarantee for any debt securities issued by these two companies. This was the French method of supplying state aid to banks by means of a guarantee rather than directly. Through this Act, the French state essentially became a lender of last resort. ${ }^{83}$ Throughout the crisis, soft forms of protectionism and limited foreign penetration remained features of the French banking system, while there was only an initial and temporary upswing of intervention as a result of the crisis. ${ }^{84}$

In addition, more recent policy shifts presented in the Loi Macron, ${ }^{85}$ passed in late 2015 , has had a number of interesting effects on French employment and labour as it aims generally to create more business friendly policies in line with the post-financial crisis need to liberalise the French economy. ${ }^{86}$

\section{i. Wages}

Short time working regimes were introduced in France as a result of the financial crises. ${ }^{87}$ Short time working refers to the option of an employer to essentially "lay off" employees for a period of time each week or to reduce working hours on a daily basis in order to save money for the company.

\section{ii. Hiring and Firing}

The statute of limitations for claims relating to the performance or termination of the employment contract was reduced from five to two years and to three years for salary related claims (in stark contrast to the 3 months' limitation period in the UK for employment tribunal claims!) France has also introduced an enticement to engage in alternative dispute resolution by introducing minimal lump sum compensation for employees willing to settle at a conciliation hearing before the labour court in dismissal cases. ${ }^{88}$

\section{iii. Redundancies}

In May 2013, France passed a Job Security Bill that introduced a number of reforms to the labour code relating to the rules governing collective redundancies. The new legislation affords employers a greater choice as to the procedure they follow when considering

\footnotetext{
${ }^{82}$ David Howarth, "France and the International Financial Crisis: The Legacy of State Led Finance" (2013) 26(3) Governance: An International Journal of Policy, Administration, and Institutions 369, 374 \& 377-382.

${ }^{83}$ Cavalier (n81) 788.

${ }^{84}$ Howarth (n82) 374 \& 389.

${ }^{85}$ Loi no 2015-990 du 6 août 2015 pour la croissance, l'activité et l'égalité des chances économique.

${ }^{86}$ See for example, The Economist, "Macron's Gambit" available form <http://www.economist.com/news/europe/21635835-economyminister-must-convince-brussels-his-reforms-are-liberal-and-paris-they-are-not-macrons $>$ accessed 26 December 2016.

${ }^{87}$ Clauwaert and Schomann (n18) 10.

88 J-F Gerard, "International Labour Law Bulletin" Freshfields Bruckhaus Deringer Summer 2013 available from http://www.freshfields.com/uploadedFiles/SiteWide/Knowledge/36343 FINAL\%20PDF.pdf first accessed 26 September 2014.
} 
collective redundancies in a company of more than 50 employees considering the dismissal of more than 10 within 30 days, triggering a job protection plan. This process was previously quite strict and required time-consuming and complicated information and consultation exercises with Works Councils. Employers were able to negotiate an agreement with a relevant trade union or to unilaterally implement a "social plan", which allows employers to depart significantly from standard requirements governing the number of meetings with employee representatives, timetables for dismissals, and selection criteria with the aim of speeding up the collective consultation process. Works Councils were also deemed to have been consulted even if they failed to respond within a now closed timeline. Employers were also permitted to enter into agreements with trade unions under which employees agreed to detrimental changes to their terms and conditions in return for a commitment by the employer not to implement any redundancies during the term of the agreement, not exceeding two years. ${ }^{89}$

France also added additional protections following the financial crisis. It adopted a law specifying that in the event that collective redundancies result in the offer of a new post abroad, remuneration must be equivalent to that paid in France. Further, the Court of Cassation ruled that contracts terminated by mutual consent for economic reasons in the context of a workforce reduction should also be counted within the number of intended redundancies, thus counting toward the thresholds of collective redundancies, which may then indicate the requirement for an employment safeguard plan to be put in place. Termination by mutual agreement can therefore not be used to circumvent the protections in place for employees subject to redundancy. ${ }^{90}$

\section{iv. Access to Social Welfare}

France has extended the maximum duration of compensated partial or technical unemployment and increased its compensation rates for the same. In addition, it made it easier to access the benefit system for those with short working records. ${ }^{91}$ France also extended its unemployment insurance agreements to better benefit the most precarious workers by reducing the minimum contribution period for unemployment insurance entitlement from six to four months. In addition, France offered a one off 500 Euro payment for young people lacking a substantial work history. Finally, the Professional Transition Contract has now been extended to workers in companies of all sizes and offered $80 \%$ replacement of previous gross salary and intensive job-seeking assistance for a year to those workers who have been made redundant for economic reasons. ${ }^{92}$

\section{v. Collective Bargaining}

Since the financial crisis of 2007 , there was a further move toward making it possible for lower level bargaining to deviate unfavourably from higher level collective agreements or even statutory legislation. ${ }^{93}$ Legislation in 2004 first made it easier for company agreements to diverge from industry level agreements, which was extended to working time by legislation in 2008. More recent legislation passed in June 2013 has implemented an

\footnotetext{
${ }^{89} \mathrm{Ibid}$ and J-M Sainsard and C Noblet, "France Introduces Radical Labour Market Reforms" Squire and Sanders, available from and http://www.squiresanders.com/files/Publication/5fdc90a3-c1d2-4c6a-b71d-ab4fc7429426/Presentation/PublicationAttachment/0fbce78735f0-4c05-becd-b2a7e4620235/France-Introduces-Radical-Labour-Market-Reforms-Newsletter.pdf, first accessed 26 September 2014.

${ }^{90}$ Muller (n28) 8.

${ }^{91}$ Clegg (n34) 11.

${ }^{92}$ Ibid 13.

${ }^{93}$ Clauwaert and Schomann (n18) 10 and 14
} 
agreement on job security, though it also provisions for the possibility of companies in financial distress to reduce some pay rates and to make changes to working time in exchange for employment guarantees. However, use of these agreements have been limited to date. ${ }^{94}$ The introduction of such provisions do indicate the recognition of the need to make allowances to diverge from protective norms in the event that an employing company is in financial difficulties.

\section{The United Kingdom}

While the UK experienced a sudden economic shock in terms of bankruptcies, decrease in consumer demand, drops in gross domestic product growth, and an increase in unemployment, it differs from France, Greece and Portugal in several significant ways. It is not part of the Single Monetary Union; it follows a liberal approach to the economy, and adopts a light touch to any kind of interventionist regulation, ${ }^{95}$ which was only enhanced through deregulation as a result of the economic crisis; and its financial structure was highly internationalised. As a result of this latter characteristic, it was one of the first European countries to be heavily hit by the global crisis due to its strong ties with the financial sector of the United States. The UK government injected billions of pounds into the failing banking sector through direct financial input, government guarantees of bank issuances, and the purchase of toxic bank equities. $^{96}$

In terms of social and unemployment problems precipitated by the financial crisis, Britain took a distinctly laissez faire approach, unwilling to improve, even temporarily, the already comparatively low support provided in unemployment. The UK's approach to tackling the crisis was characterised mostly by tax cuts in an attempt to boost economic activity, while little was done to address those becoming unemployed, differing significantly in approach of the rest of Western Europe. ${ }^{97}$ It did initiate demand led measures in reaction to the rising unemployment, which amounted to incentives for employers to hire long term unemployed and funding programmes aimed at getting the unemployed back to work. ${ }^{98}$

In addition, the UK proceeded to deregulate the labour market in a number of areas, including discrimination and equality. It has repealed provisions in the Equality Act 2010 relating to combined protective characteristics and third party harassment on the grounds that they are perceived as burdens on business. The duty on public authorities to have regard to the need to reduce socio-economic inequalities was repealed (though it never entered into force) and the duty on large employers to publish details of the gender pay gap was not implemented. ${ }^{99}$

The UK also implemented a new employee shareholder status, in which employees can agree in exchange for shares with a minimum value of $£ 2000$ in the employer company to waive certain employment rights such as the right not to be unfairly dismissed, the right to statutory redundancy pay, entitlement to request flexible working except in limited circumstances, and the entitlement to request training or study. Employee shareholders are also subject to longer

\footnotetext{
94 ETUI website, Collective Bargaining in France, available from http://www.worker-participation.eu/National-IndustrialRelations/Countries/France/Collective-Bargaining accessed 26 February 2017.

${ }^{95}$ Iain MacNeil, "The Trajectory of Regulatory Reform in the UK in the Wake of the Financial Crisis" (2010) 11 European Business Organisation Law Review 483, 484.

${ }^{96}$ Heejung Chung and Stefan Thewissen, "Falling Back on Old Habits? A Comparison of the Social and Unemployment Crisis Reactive Policy Strategies in Germany, the UK and Sweden" (2011) 45(4) Social Policy \& Administration 354, 358 \& 362.

${ }_{97}$ Barbara Vis, Kees van Kersbergen and Tom Hylands, "To What Extent Did the Financial Crisis Intensify the Pressure to Reform the Welfare State?" (2011) 45(4) Social Policy \& Administration 338, 347.

${ }^{98}$ Chung and Thewissen (n96) 363.

99 Bob Hepple, "Back to the Future: Employment Law under the Coalition Government" (2013) 42(3) ILJ 203 , 207.
} 
notice periods before returning from maternity or paternity leave. While the waiver of employment rights does not preclude claims relating to discrimination and employees are required to take independent legal advice, entitled to a detailed statement of terms; and subject to a seven day cooling off period, the implications of this new form of contract essentially undermines the cornerstone of UK employment law: the employment contract. ${ }^{100}$ It is yet to be seen what effect this new status may have on the equality in the employment relationship, bargaining power, and the relative security of employment.

While most countries took action in relation to benefits for the unemployed affected by the financial crisis, Britain took a decidedly apathetic approach. It had the least supportive system for the unemployed prior to the crisis and proved to be the most reluctant government to improve its policies in the light of the critical economic conditions. Instead, Britain introduced employment subsidy schemes to benefit employers hiring the long term unemployed and focussed on other means of activating the unemployed in the country. ${ }^{101}$

\section{i. Wages}

The lack of intervention by the UK government led to the involvement in social partners in agreeing to collective agreements that reduced working hours and wages in order to save jobs, though in many cases massive redundancies were still unavoidable. The median pay settlement dropped and occupational pensions have been cut. ${ }^{102}$

\section{ii. Atypical Contracts}

Zero-hours contracts became common usage in the UK. These contracts mean that there is no obligation on the employer to provide work or for workers to accept it, but it also often means that employees are not permitted to work for another employer at the same time, ${ }^{103}$ leaving them in a precarious financial position. While a flexible workforce is one of the reasons cited for the UK pulling away from France and the rest of the Eurozone in terms of GDP growth, but the zero hours' contract may also be creating a low-wage underclass to be summoned peremptorily by employers on a whim in a repeat in what might be recognised as a Victorian style industrial relationship.

\section{iii. Hiring and Firing}

Unfair dismissal rules have been substantially changed. Employees must now work for a minimum of two years' continuous service rather than one year to qualify to claim unfair dismissal at an Employment Tribunal. Compensation has also been restricted to the lower of a specified amount not exceeding three times the median annual earnings of an employee or a specified number of not less than 52 weeks multiplied by a weeks' pay of the employee. ${ }^{104}$

\section{iv. Redundancy and Acquired Rights}

The global economic crisis inevitably led to redundancies in the workplace, particularly relevant in those jurisdictions such as the United Kingdom that has relatively weak

\footnotetext{
100 Jeremias Prassl, "Employee Shareholder "Status: Dismantling the Contract of Employment" (2013) 42(4) ILJ 307, 312-315 and Gerard (n88).

${ }^{101}$ Clegg (n34) 5 \& 9.

102 Chung and Thewissen (n96) 363.

103 "Zero Hours Contracts" ACAS

${ }^{104}$ Hepple (n99) 207-208.
} 
protections in place against collective dismissals. ${ }^{105}$ The UK has undertaken to comply only minimally with EU obligations for worker protective obligations going forward, and the spectre of Brexit may only see these protections further eroded. Conditions governing economic dismissals were softened and thresholds loosened in order to increase labour market flexibility, making it easier for businesses to lay off workers in the UK. ${ }^{106}$ In particular, the consultation period for collective dismissals was shortened from 90 to 45 days for redundancies of more than 100 employees (the EU minimum is 30 days) and now excludes fixed term contracts that have reached their agreed termination date from collective redundancy obligations. ${ }^{107}$ There have also been reduced protections under the TUPE regulations: contractual conditions can now be more easily altered if the changes are connected with the transfer but are for an economic, technical or organisational reason entailing changes in the workforce; dismissals are no longer automatically unfair for changes in workplace; collective agreements can be renegotiated a year after the transfer; and it is now more difficult to satisfy the criteria of a service provision change (the work must be fundamentally the same). ${ }^{108}$

\section{v. Access to Social Welfare}

In Britain, there was a nearly complete absence of any improvement in income support measures. ${ }^{109}$ In fact, it has become increasingly difficult for the most vulnerable in society to access social benefits associated with loss of employment.

\section{vi. Access to Justice}

The UK has had a highly flexible labour market in comparison with other EU member states. However, it could be said that the financial crisis and its effects on labour markets throughout the EU provided an opportunity to further reduce employment rights through deregulation. Most significant perhaps is the fact that the UK made it more difficult for employees to access justice for unfair dismissal and indeed any other employment related claim by instituting fees for employment tribunals and appeals. In addition, the rules on continuity of service have increased from one year to two years, which means employees have to work for two continuous years before a dismissal can be subject to the scrutiny of a tribunal. ${ }^{110}$ There are also now fees applied to filing tribunal claims, ${ }^{111}$ which affects not only unfair dismissal claims, but those relating to discrimination and other socially important aspects of employment law. The UK has also promoted alternative dispute resolution mechanisms over tribunals. $^{112}$

\section{Impact of Financial Crisis on Rescue Regimes}

It is clear that employment benefits, job security, and worker protections have reduced in every EU member state since the financial crisis of 2007 and the subsequent sovereign debt crisis. While it is clear that this creates more a precarious situation for employees throughout the EU, it is not only through employment regulation that such protections may arise. The

\footnotetext{
${ }^{105}$ Nascimento (n19) 50.

${ }^{106}$ M Magone, "Portugal" (2009) Volume 48 European Journal of Political Research 1080-1086, 1081.

${ }^{107}$ Hepple (n99) 207-208.

108 ACAS "2014 Changes to TUPE” (2014) Ref AL20 available from http://www.acas.org.uk/media/pdf/1/1/9908-2901767-TSO-ACASTUPE_is changing-ACCESSIBLE.pdf first accessed 26 September 2014

${ }^{109}$ Clegg (n34) 10.

${ }^{110}$ Hepple (n99) 206

${ }^{111}$ Clauwaert and Schomann (n18) 13.

${ }^{112}$ Ibid 14
} 
rescue culture has also created an environment aimed at preserving employment through the preservation of businesses or of enterprises. As such, the impact of the financial crises on EU rescue regimes throughout the member states is also a relevant consideration as improvements in this area of law could bridge the gulf left by the reduction in protection provided through employment regulation. As such, the following section will discuss and analyse relevant changes to rescue regimes in Greece, Portugal, France, and the UK with a view to determining whether the rescue culture itself provides an embankment for those rights that have been lost through the flexibilisation of the labour market occurring in response to the financial crises of the first two decades of this second millennium.

There have been a number of reforms to insolvency and corporate rescue laws throughout the EU in the early 2000's and then just following the financial crisis with aims of supporting a rescue culture, though the various regimes under examination here have found themselves at different depths along the stream of rehabilitation and recovery. These regimes have operated with varied success as an effective embankment for the protection of failing businesses and the social and economic welfare associated with them. For the purpose of this article, the focus of attention will be on pre-insolvency rescue procedures.

\section{Greece}

Prior to the reforms of 2007, Greece lacked any kind of sophisticated corporate rescue regime. Rather its insolvency system was geared towards liquidation, which has historically resembled the French insolvency system. Rehabilitation under the old system was only theoretically possible through a settlement of debts between the debtor company and its creditors by way of a voluntary reorganisation through a direct creditors' agreement, though this method did not provide for a "cram-down" on dissenting creditors. ${ }^{113}$

The 2007 Insolvency Law ${ }^{114}$ aimed to update an outdated system by introducing radical changes to the Greek insolvency philosophy, providing for the rescue of ailing companies and offering a second chance to insolvent debtors. It provided for quick and easy access to rehabilitation procedures and was primarily designed to ensure the rescue of viable distressed companies and associated preservation of employment. It introduced the conciliation and judicial reorganisation procedures. Conciliation was a debtor in possession procedure similar to the French procedure of the same name that was designed to rehabilitate the business and to preserve employment. A debtor in financial difficulties would apply to the court to initiate a conciliation procedure, including a plan for extricating itself from its difficulties. If satisfied, the court would appoint a conciliator with the task of achieving an agreement between the debtor company and its creditors in order to overcome the company's financial distress and safeguard its survival. ${ }^{115}$ The debtor would then be immune to individual enforcement for a period of two years while the reorganisation plan was being implemented. However, the conciliation procedure proved inadequate to the task due to its consensual basis and lack of cram-down. The requirement to appoint a conciliator or mediator also led to a lengthy process that made it impossible to bring the parties to agreement quickly. In addition, the conciliation procedure has been abused by debtors as a means of securing a preliminary order prohibiting creditors from enforcing their claims, thus leading to procedural abuse. ${ }^{116}$

\footnotetext{
${ }^{113}$ A Kastrinou, "European Corporate Insolvency Law: An Analysis of the Corporate Rescue Laws of France, Greece and the United Kingdom" (2009) Thesis submitted for the degree of Doctor of Philosophy at the University of Leicester, 170-204, 171-172 \& 190-194.

${ }^{114}$ Law 3588/2007 enacted on 10 July 2007.

${ }^{115}$ Kastrinou (n113) 170-204, 171-172 \& 190-194.

${ }^{116}$ Stathis Potamitis and Alexandros Rokas, "A New Pre-Bankruptcy Procedure for Greece" (2012) 3 JBL 235, 235-237.
} 
In 2011, a new law was passed that replaced conciliation with rehabilitation. ${ }^{117}$ This revised procedure allows a debtor to obtain the ratification of a restructuring plan agreed with the requisite majority of creditors without any other judicial assistance or protection. The debtor can also submit an application for the opening of negotiations with creditors in which it can seek the appointment of a mediator to facilitate negotiations or it can seek to negotiate directly with a creditors' committee, or on a bilateral basis where a qualified majority of creditors negotiate directly with the debtor company. This procedure is technically prebankruptcy, but the debtor company must show that it is in a state of financial weakness. Crucially, following the reforms of 2015, access to the procedure has been improved and is no longer draconian. Access to the rehabilitation procedure is no longer restricted to companies that are actually insolvent and perhaps already too far downstream to be rescued, or on the verge of insolvency. Although it is not necessary to demonstrate that the debtor is in actual cessation of payments, the court must be persuaded that the debtor is likely to become insolvent. A moratorium can also be put into place through a preliminary order by the court after an application for rehabilitation proceedings has been received. ${ }^{118}$

While the new rehabilitation is a clear improvement ${ }^{119}$ over the conciliation procedure, it also has serious obstacles to overcome in order for it to make any significant contribution to rescuing companies, saving jobs and maximising value for the financially distressed debtor company's stakeholders overall. ${ }^{120}$ The process is also still overly dependent on the Greek judicial system. ${ }^{121}$ In addition, it has been argued that there might be a risk of misuse of the procedure by solvent companies seeking to force a compromise with their creditors, although fully capable of meeting their existing obligations. ${ }^{122}$

Furthermore, while a pre-pack style of procedure is available in Greece, it requires a number of months and contested hearings under Greek procedural requirements. Greek business culture is also an issue given that the success of a rescue procedure depends on residual trust and good faith between the debtor and its stakeholders. Greek business culture tends to be suspicious of these processes, viewing them as a prelude to default and often precipitating damaging responses from suppliers and banks. The abuse of the previous system does not help in this negative view. ${ }^{123}$ However, more recently further steps ${ }^{124}$ have been taken for the modernisation of the Insolvency Code in order to create an attractive and efficient environment for all the parties involved.

In addition, there have been further negotiations between the Greek government and the troika in an attempt to revive the Greek economy. The troika proposals provide for a quicker, inexpensive, and less bureaucratic registration of companies, as well as further amendments to the Greek Insolvency Code, so as to facilitate the out-of-court settlement of debts. It is proposed that the out of court "compromise" procedure will only be available to medium-

\footnotetext{
117 The rehabilitation procedure has been amended in 2015 by Law 4336/2015 (FEK A 94/14-8-15), which was introduced in order to ratify the Financial Assistance Facility agreement with the European Stability Mechanism.

118 Potamitis and Rokas (n116) 237-241.

119 The new procedure enables the majority to cram down on dissenting minority creditors, the ratification of pre-pack sales.

${ }^{120}$ For a more detailed analysis see Stathis Potamitis and Thodoris Athanassopoulos, "Greek Insolvency Law and the Greek Economic Crisis", (2012) First Quarter INSOL World 15.

${ }^{121}$ Potamitis and Athanassopoulos note that the excruciatingly slow pace of the judicial process constitutes a long term problem for the Greek Insolvency Practice. See Potamitis and Athanassopoulos (n120).

${ }^{122}$ Stergios Frastanlis, "Recent Reform of the Greek Restructuring and Insolvency Law" (2016) 13(2) ICR.

${ }^{123}$ Potamitis and Rokas (n116) 246-247.

${ }^{124}$ As a result of the Memorandum of Understanding between the European Commission acting on behalf of the European Stability Mechanism and the Hellenic Republic and the Bank of Greece, which was signed on 19 August, 2015, key reforms were introduced, such as the establishment of an Insolvency Practitioner profession, the streamlining of the special liquidation procedure and the amendment of the rehabilitation procedure (providing inter alia for the reduction of procedural costs) in order to improve the availability of the procedure and encourage early intervention.
} 
sized and large businesses. However, it is submitted that the proposals will only play a trivial role in the revival of the economy, as the proposed new procedure shall not apply to the majority of troubled businesses, namely small businesses. The Greek rescue culture is therefore still a work in progress. It is yet to be seen whether the most recent changes will result in the rescue of more viable businesses, having the concomitant effect of preserving those jobs associated with them. Thus, it is unclear if Greek employees are likely to derive any additional benefit from this revised rescue regime, though the trend of decreasing unemployment data may be a positive sign of things to come.

\section{Portugal}

Similar to the Greek Insolvency Laws, the Portuguese Insolvency Act was originally geared towards the winding-up of companies and provided struggling companies with few means of recovery. ${ }^{125}$ However, rescue procedures in Portugal are available in the Insolvency Plan, an out of court proceedings similar in form to the German Insolvenzplan as set out in the Insolvency and Enterprise Rescue Code ${ }^{126}$ in 2004. The purpose of this procedure is either to liquidate an insolvent debtor's assets and distribute the proceeds to creditors, or to satisfy creditor debt in a manner envisaged in an insolvency plan that is based on the recovery of the company. However, this plan was available only available if the company was indeed insolvent, thus not technically a pre-insolvency rescue procedure. In order to initiate the procedure, the debtor had to find it impossible to carry out financial obligations that have already fallen due. ${ }^{127}$

The Portuguese MoU required that reforms be introduced that facilitate more effective rescue of viable firms, including fast-tracking court approval procedures for restructuring plans. Thus, Portuguese legislators introduced reforms in 2012 that added a new hybrid proceeding to the insolvency plan aimed only at pre-insolvency situations, the "special revitalisation proceeding". It is available to those companies facing economic difficulties or that are in an imminent insolvency situation. The procedure is comprised of a period of negotiations between the company and its creditors with the aim of agreeing to a restructuring plan. Once agreed by a qualifying majority of creditors and approved by the court, the plan becomes binding upon all creditors, whether dissenting or not. ${ }^{128}$ Since its implementation, the new revitalisation procedure has seemed popular among a number of different debtors, companies and individuals alike. ${ }^{129}$

There are, however, certain weaknesses in this new procedure. While it is advantageous that the restructuring can now be carried out without the company being declared insolvent, in the event that negotiations do not arrive at an equitable solution, the company then risks being declared insolvent and subject to the opening of proceedings. ${ }^{130}$ Part of the problem here is, like Greece, a cultural suspicion of debt and insolvency is still present. If the debtor is unable to satisfy the creditors that any compromises made will be worth engaging in the process, those creditors might well initiate insolvency proceedings in order to protect themselves from

\footnotetext{
${ }^{125}$ Catarina Serra, "Amendments to the Portuguese Insolvency Act - Much ado about nothing?" (2012) Volume 49 Eurofenix - The Journal of INSOL Europe 14-17.

${ }^{126}$ Decreto-Lei 200/2004

${ }^{127}$ A P Matos Martinas and M J Andrade Campos, "Portugal" Chapter 3 in Christopher Mallon (ed), The Restructuring Review (Law Business Research Ltd 2010) 275, 276-277.

${ }^{128}$ Catarina Serra, "The Rescue of Large Corporations-How Suitable is the Portuguese Insolvency Act?" (2013) in R Parry (dd.), Papers from the INSOL Europe Academic Forum / Nottingham Law School Joint International Insolvency Conference, Nottingham Trent University, Nottingham, United Kingdom, 28 \& 29 June 2012, 2013, 97-105, 97-99.

${ }^{129}$ Catarina Serra, "In the Eye of the Crisis - A Portuguese Perspective" (2013) Second Quarter INSOL World - The Quarterly Journal of INSOL International, 24-25.

${ }^{130}$ Serra (n128) 97-99.
} 
what they may view as an untenable or even unscrupulous process. That said, the 2012 reforms did make changes to the classification of insolvency, which had before been associated with the finding of guilt for those causing the financial troubles. It is no longer compulsory unless there is evidence of intentional or grossly negligent conduct by the company directors. ${ }^{131}$

The 2012 amendments did not, however, provide any reformative measures for the insolvency plan, despite the undisputed flaws in the regime. Thus it remains equally difficult for insolvent companies, even though still viable, to escape liquidation. The absence of amendments to the insolvency plan, in addition to the shortening of the term to file for insolvency, make a company's position under Portuguese insolvency law that much more pressured, rather than alleviating the stress. ${ }^{132}$ Where difficulties for businesses are encountered, so too are risks for employees, thus it is also unlikely that the most recent changes made to Portuguese corporate rescue procedures will provide any additional security for employees at this stage.

\section{France}

France might be considered the inventor of the concept of corporate rescue, beginning in 1967 even prior to the legendary Chapter 11 procedure of the United States introduced in 1978 that many systems now try to emulate. In the 1990s the mandataire ad hoc and the amicable settlement provided preventative pre-insolvency procedures. The Law of $2005^{133}$ revised the ad hoc mandate and replaced the amicable settlement with conciliation. The ad hoc mandate is a procedure whereby a third party is appointed by a presiding judge to consider possible solutions to the debtor's problems and are usually governed by case law rules rather than by statute. The conciliation procedure is a type of mediation open to businesses in foreseeable or acknowledged difficulty, as well as those already in a state of cessation de paiements. The procedure gives creditors the opportunity to agree a legally binding agreement with the debtor company. ${ }^{134}$

The Law of 2005 also introduced the procedure of sauvegarde (preservation) as an up-stream option to the conciliation and ad hoc procedures, aimed at early intervention in a failing company. However, and without leaving much time for the new procedure to become integrated into practical usage, its perceived underutilisation led to a reform in 2008. The Ordinance of $2008^{135}$ made major changes to all of the procedures contained within the French insolvency system. The bulk of its provisions addressed the perceived deficiencies of the sauvegarde procedure. ${ }^{136}$

The global financial crisis also led to changes in practice which prompted further reforms in the Law of 2010, ${ }^{137}$ introducing a French style of pre-pack in a new procedure called the sauvegarde financière accélérée (accelerated financial preservation). Designed mainly for larger companies, it allowed a company undergoing conciliation to enter into the sauvegarde if they had a plan that they could convince the court would assure the continuation of the business and command the support of a majority of creditors. These procedures, out of the

\footnotetext{
${ }^{131}$ Catarina Serra, "Country Reports: Portugal - the New Portuguese Insolvency Act" (2012) Volume 47 EuroFenix - The Journal of INSOL Europe 40

${ }^{132}$ Serra (n125).

${ }^{133}$ Law No. 2005-845 of 26 July 2005.

${ }^{134}$ J R Silkenat and C D Schmerler, The Law of International Insolvencies and Debt Restructurings (Oceana Publications 2006) 146-150.

135 Ordinance no. 2008-1345 of 18 December 2008.

${ }^{136}$ Paul J Omar, “A Reform in Search of a Purpose: French Insolvency Law Changes (Again!)” (2014) 23(3) IIR 201.

${ }^{137}$ Law no. 2010-1249 of 22 October 2010.
} 
range available among the four jurisdictions under study herein, appear to be the most advanced, up-stream, pre-insolvency procedures available, perhaps throughout the whole of the EU. However, the continued impact of the financial crisis, the impact of the Eurozone crisis, concerns about the continued viability of French businesses, and chronic underemployment has led to yet another set of reforms in 2014. This was preceded by a review and a report on the state of insolvency that stated that the principal objectives for any reform would be to facilitate the anticipation of worsening economic conditions by businesses, to reinforce the efficiency of procedures by adjusting the impact to creditors, debtors and others, to adapt to the prevailing reality of the treatment of businesses in an irremediable and compromised situation, while at the same time respecting the relative rights of creditors and debtors as well as to ensure greater security, simplicity and effectiveness. ${ }^{138}$ The result was an Ordinance of 2014, ${ }^{139}$ which introduced two new procedures: sauvegarde financière and the rétablissement professionnel, both of which are dependent upon another procedure previously being engaged. The former is a variation on the sauvegarde theme as an agreement among the principal creditors and the debtor and contains a cram-down element, while the latter deals with impecunious estates. The sauvegarde financière has the advantage of speed and efficiency in terms of not losing business value and is intended not to affect employees at all. ${ }^{140}$

While the frequency of reform in France is great and perhaps, due to that fact, confusing, it also shows a willingness to change with the time in such a way as to keep improving the effectiveness of corporate rescue processes. France's inherent concern for its workers is also supported by the constant improvement of corporate rescue as this inevitably assists in maintaining a higher level of job security. Thus, despite some decrease in employment protection in France, its seemingly effective up-stream and highly responsive rescue regime may well provide some relief in terms of job security that may have been lost following the introduction of some flexibilising factors in the last few years by ensuring the preservation of viable businesses and those jobs associated with them.

\section{United Kingdom}

The most significant reforms to insolvency law in the United Kingdom in the most recent past occurred seven and five years before the beginning of the crisis with the Insolvency Act $2000^{141}$ Enterprise Act 2002, both of which came into force on 2 November 2002. ${ }^{142}$ These Acts modified the Insolvency Act 1986 by replacing certain of its provisions with new sections and schedules aimed at improving rescue procedures in terms of efficiency, benefit, and practical use. The 2000 Act reformed the Company Voluntary Arrangements ("CVA"), a pre-insolvency procedure which now provides small companies with the option of a moratorium, while the 2002 Act reformed the administration procedure. The latter of these has had arguably the most significant effect on the UK rescue culture as it went further to protect unsecured creditors, streamlined the procedures, and was implemented despite the resistance of banks, financial institutions, and other primary lenders who had benefitted from the exclusive control that administrative receivership had allowed. ${ }^{143}$ The new procedure

\footnotetext{
${ }^{138}$ Rapport au Président de la République relative à l'ordonnance no. 2014-326 du 12 mars 2014 portant réforme de la prévention des difficultés des entreprises et des procédures collectives ("Presidential Report") in the Introduction.

${ }^{139}$ Ordinance no. 2014-326 of 12 March 2014.

${ }^{140}$ Omar (n136).

${ }^{141}$ Insolvency Act 2000 c. 39

142 Enterprise Act 2002 c. 40.

143 The Enterprise Act 2002 also abolished administrative receivership which was a procedure that could be initiated by a floating charge holder holding security over all or most of the company's assets through which it could appoint an administrative receiver to act on their
} 
presents three hierarchical objectives: to first try to rescue the company as a going concern, or to achieve a better result than would be achieved in liquidation. Finally, if the first two options were unattainable, an insolvency practitioner could seek to realise property in order to make distributions to secured or preferential creditors. ${ }^{144}$ It is not, however, a pre-insolvency procedure in its purely statutory form.

However, one could argue that the pre-pack administration does function as a pre-insolvency type of mechanism, though it is a non-statutory practice process that functions on the premise of a pre-packaged sale by an administrator on terms that have been agreed before the administration is commenced, but which is carried out shortly after the appointment of an administrator. ${ }^{145}$ This process avoids the disruption to business common to normal insolvency procedures and also reduces the potential reputational damage due to its secretive nature. While the secretive nature of pre-packs has come under scrutiny in recent years, particularly with regard to their effects on employment protection, they are very commonly used and constitute an important element of the UK's insolvency procedures. ${ }^{146}$ With particular regard to the protection of workers' rights, while UK case law confirms that the TUPE regulations would apply to transfers occurring out of pre-pack administrations, ${ }^{147}$ this has not been a particularly serious issue in practice, due to the way that pre-packs are used: mainly as a tool for debt restructuring. ${ }^{148}$ The pre-pack procedure has proven to be a useful debt restructuring mechanism, which has attracted many ailing businesses within the UK, as well as businesses operating outside the UK. However, in the sphere of international insolvency law, the strict application of the TUPE regulations on pre-packs, combined with reforms of the insolvency and rescue rules of other jurisdictions, may render the UK pre-pack tool less competitive for foreign companies that might have sought to re-organise their financial affairs elsewhere. However, in light of the recent decision of the UK to exit the EU, one must wait for further developments, as the UK may in the near future find itself able to disregard completely the application of the TUPE Regulations.

In addition, the CVA is a pre-insolvency mechanism that is sometimes used as a freestanding and sometimes in conjunction with an administration or a pre-pack procedure. The CVA is a compromise between the debtor company and its creditors that facilitates the rehabilitation of the struggling company without having resort to a formal insolvency procedure, which could otherwise consume the assets of the company. As a debtor-friendly procedure, it also encourages companies to seek help at an earlier stage of their difficulties. ${ }^{149}$ It could also be argued that the amendments that were introduced to the CVA by the Insolvency Act 2000 addressed key inadequacies ${ }^{150}$ of the procedure and also clearly demonstrated the shift towards a corporate rescue culture in the UK. Notwithstanding the reforms to the CVA procedure, its use has been limited. This could be due to the fact that the long-awaited reforms took place a little too late, or simply due to the fact that the new streamlined administration provides greater protection to the debtor company by means of a moratorium, which is available to all companies regardless of their size, hence overshadowing the CVA.

behalf to exercise their security rights, putting them in control of the company assets and generally leading to liquidation and low to no returns for other creditors.

${ }^{144}$ Paul J Omar and Jennifer L L Gant, "Corporate Rescue in the United Kingdom: Past, Present and Future Reforms" (2016) 24 Insolv LJ 40.

${ }^{145}$ David Ereira, "UK Restructuring and Insolvency Law: Current and Future Trends" (2010) April Practical Law Publishing Limited 23.

${ }^{146}$ Kate Creighton-Selvay, "Pre-packed Administration: an Empirical Social Rights Analysis" (2013) 42(2) ILJ 85, 88.

${ }^{147}$ See Key2Law v De'Antiquis \& Anor [2011] EWCA Civ 1567.

${ }^{148}$ Creighton-Selvay (n146) 112.

${ }^{149}$ Omar and Gant (n144).

${ }^{150}$ Prior to the enactment of the Insolvency Act 2000, the CVA procedure was of limited use to small ailing companies, as it lacked a moratorium. Importantly, the 2000 Act introduced a moratorium for small businesses, (which is available to a company that chooses to use it) which imposes a temporary stay on all claims against the company and allows it with a short respite, so as to design a rescue plan. 
Finally, the flaws of the original CVA procedure discouraged insolvency practitioners, who, as a result never really embraced it and relied on alternative procedures, such as the pre-pack and schemes of arrangement. ${ }^{151}$

In addition to the CVA, the Scheme of Arrangement, ${ }^{152}$ although not technically within the remit of insolvency law provides another mechanism through which companies can deal with their financial problems at an earlier stage. A scheme of arrangement allows a company to reach a compromise with its creditors, or any class of its creditors, or with its members, or any class of them. A scheme may also be used by a group of companies and it can prove particularly useful where the group is seeking to hive off any of its underperforming elements. As opposed to the CVA, ${ }^{153}$ a scheme involves a complex voting structure. However, once a reorganisation plan is approved it becomes binding on all creditors. In addition, it is important to note that, under a scheme of arrangement, it is not necessary to consult any class of creditors who have no real economic interest in the company, hence their votes on the scheme may be disregarded.

Thus there are a number of options for up-stream pre-insolvency procedures in the UK, providing a means of preserving business and, by association, employment. However, the employment protection regime in the UK does not provide a high level of protection that can be depended upon in or outside of insolvency situations. Thus, while the rescue regime in the UK is clearly advanced and generally effective, the lack of comparative employment protection is unlikely to be sufficiently counterbalanced by the employment preservation provided by the rescue regime as job security is simply not a focus of social policy to the same level that one finds in France, for example. That said, of the four jurisdictions examined herein, the UK has remained the jurisdiction with the lowest unemployment rates since the financial crisis of 2007.

\section{Conclusion}

The employment protection and corporate rescue reforms often differ in their fundamental functions, but are both important aspects of a healthy economy. Excessive inequalities in terms of wages and productivity have been at the root of depressions and economic recessions during the modern era. Such imbalances heighten the risk of economic failure. A growing wage and productivity gap upsets the natural mechanisms necessary to achieve economic balance. Where wages fall, so too does consumption, leading to deflation where demand is not supported. ${ }^{154}$ This also applies to the economic benefit of unemployment insurance as this helps to stabilise consumer demand in the face of economic downturns, which would otherwise be sapped by rising unemployment. ${ }^{155}$

While employment protection and other socially oriented regulation provide an important safety net for employees who are in an inherently less powerful bargaining position than employers generally, the financial crisis has seen these measures reduce in strength throughout the EU, except exceptionally perhaps for France. As these measures reduce in strength, employee rights in insolvency also fall behind as redundancy, dismissal, collective agreements and transfer of undertakings are often implicated in insolvency and rescue

\footnotetext{
${ }^{151}$ A Kastrinou, "Comparative Analysis of the Informal Pre-Insolvency Procedures of the UK and France" (2016) $25(3)$ IIR 163.

${ }^{152}$ Companies Act 2006 c. 46 s.895.

153 Once an agreement is reached under the CVA it is only binding upon creditors who were eligible to vote, or who would have been eligible to vote, if they had notice of a creditors' meeting.

${ }^{154}$ S Lansley, "Inequality, the Crash and the Ongoing Crisis" (2012) 83(4) The Political Quarterly 754, 756-757.

${ }^{155}$ Clegg (n34) 8.
} 
processes. If one looks at corporate rescue not only as a means of preserving economically viable businesses, but also as a part of the social aims of employment protection, there arises an additional reason to ensure that corporate rescue processes are effective: the protection of the employees. The rescue culture might provide another level of employment protection, an embankment against the ravages of economic recession and crisis, in which an effective rescue system might help to alleviate some of the severity of the effects that the financial and sovereign debt crisis have had on the rights and security of employees and workers.

In terms of how these four regimes have fared in the rescue culture mission to preserve business and associated employment, it would appear that all have taken steps forward in progress. However, Portugal and Greece have some distance to travel before they attain the level of the French system and, indeed, so does the UK. Indeed, the changes made to the rescue regimes of Portugal and Greece do not yet appear come close to effectively rescuing enough viable businesses to make any real difference with respect to employment preservation. While France has both a protective employment regime and an effective rescue culture, employment data continues to demonstrate that despite these protections in place, France has trailed behind the UK in unemployment rates since the financial crisis, and continues to do so at the time of writing in 2017.

What, then, does this mean in terms of the effectiveness of a rescue culture in comparison to the level of employment protection and whether the two can supplement each other to enhance employment preservation? It could be that for the two peripheral member states examined herein that their introduction to the Euro occurred at a time when their economies were not sufficiently prepared or advanced enough to compete on the levelled playing field of competition that this created in the EU. There is certainly evidence of this in Portugal's financial struggles in 2001. In addition, the Greek labour economy was and is of such a different form compared to other Western European countries that it is not surprising that obstacles were encountered following political and financial integration. But even more telling and perhaps also perplexing is the fact that while France possesses a highly protective employment law system and an advanced upstream corporate rescue regime, Britain continues to maintain a more robust economy and lower levels of unemployment, despite lower employment protection. This may point to the value of determining an optimum balance point between business and labour as while labour protection does what it says on the tin, viable businesses are also needed in order to employ labour, making a focus on the rescue culture certainly a rational step in the direction of achieving that optimum balance that may result, in part, in stronger EU member state economies overall. 